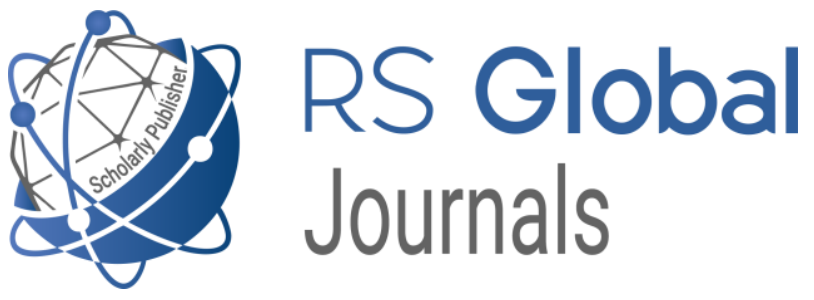

Scholarly Publisher

RS Global Sp. z O.O.

ISNI: 0000000484952390

Dolna 17, Warsaw, Poland 00-773

Tel: +48226022703

Email: editorial_office@rsglobal.pl

JOURNAL International Journal of Innovative Technologies in Social Science

p-ISSN

$2544-9338$

e-ISSN

2544-9435

PUBLISHER

RS Global Sp. z O.O., Poland

ARTICLE TITLE

ФОРМУВАННЯ ТА РОЗВИТОК ФАХОВОЇ

КОМПЕТЕНТНОСТІ ВИКОНАВЦЯ-ДУХОВИКА У

КОНТЕКСТІ ІНТЕГРАЦІЙНИХ ПРОЦЕСІВ У ЗАКЛАДАХ ВИЩОЇ ОСВІТИ УКРАЇНИ

$\operatorname{AUTHOR}(\mathbf{S})$

Закопець Михайло Львович

Zakopets M. L. (2021) Formation and Development of

Professional Competence of the Wind Instrument Performer in the

ARTICLE INFO

Context of Integration Processes in Higher Education Institutions of Ukraine. International Journal of Innovative Technologies in Social Science. 2(30).

doi: 10.31435/rsglobal_ijitss/30062021/7558

DOI

https://doi.org/10.31435/rsglobal_ijitss/30062021/7558

RECEIVED

23 April 2021

ACCEPTED

31 May 2021

PUBLISHED

04 June 2021

(c) ()

LICENSE

This work is licensed under a Creative Commons Attribution

4.0 International License.

(C) The author(s) 2021. This publication is an open access article. 


\title{
ФОРМУВАННЯ ТА РОЗВИТОК ФАХОВОЇ КОМПЕТЕНТНОСТІ ВИКОНАВЦЯ-ДУХОВИКА У КОНТЕКСТІ ІНТЕГРАЦЙНИХ ПРОЦЕСІВ У ЗАКЛАДАХ ВИЩОЇ ОСВІТИ УКРАЇНИ
}

\author{
Закопець Михайло Львович, аспірант Рівненського державного гуманітарного університету, \\ м. Рівне, Україна, ORCID ID: https://orcid.org/0000-0002-8368-6495
}

DOI: https://doi.org/10.31435/rsglobal_ijitss/30062021/7558

\section{ARTICLE INFO}

Received 23 April 2021

Accepted 31 May 2021

Published 04 June 2021

\section{KEYWORDS}

competence approach, professional competence, integration, institutions of higher education, the wind instrument performer.

\begin{abstract}
Increased intensification of intercultural and interethnic interactions has led to the integration of Ukrainian music education into the European space. As Ukraine actively cooperates with European countries in the field of education, it is quite natural that in native higher education institutions the accents and views on training specialists, including wind instrument performers, who play the role of instrumentalists, conductors, teachers, organizers, began to change.

The article highlights the main views of scientists and teachers on the specifics and versatility of the concept of "professional competence", analyzes the essence and significance of the competence approach and ways to implement it in the system of higher education in Ukraine.

Besides, the research identifies and scientifically substantiates the peculiarities of the formation of professional competence of the wind instrument player in process of training in higher education institutions, as well as identifies the following musical competencies in the structure of professional training: theoretical and methodological; instrumental and performing; creative and reproductive; social active; personal and psychological.
\end{abstract}

Citation: Zakopets M. L. (2021) Formation and Development of Professional Competence of the Wind Instrument Performer in the Context of Integration Processes in Higher Education Institutions of Ukraine. International Journal of Innovative Technologies in Social Science. 2(30). doi: 10.31435/rsglobal_ijitss/30062021/7558

Copyright: (C) 2021 Zakopets M. L. This is an open-access article distributed under the terms of the Creative Commons Attribution License (CC BY). The use, distribution or reproduction in other forums is permitted, provided the original author(s) or licensor are credited and that the original publication in this journal is cited, in accordance with accepted academic practice. No use, distribution or reproduction is permitted which does not comply with these terms.

Постановка проблеми. У сучасному інформаційному суспільстві в нових умовах гуманізації, демократизації та інтеграції навчальний процес $є$ однією $з$ перших ланок, яка зазнає глобальних та кардинальних змін. Опора вітчизняної педагогічної системи на особистісно-творчі, комунікативні, емоційно-вольові, аксіологічні, акмеологічні основи навчання та фахової підготовки майбутніх спеціалістів, а також дотримання балансу між пізнавальними, оцінювальними та креативними парадигмами освітнього процесу зумовлюють пошук нових методів і принципів у структурі підготовки фахівців під впливом єдиного глобалізованого освітнього простору.

Оскільки музичне мистецтво є виявом духовного життя суспільства, з одного боку, і соціальним інститутом, 3 другого боку, то процес пристосування особистості до соціальнокультурних реалій відбувається через безпосередню підготовку фахівців у цій галузі, котрі, в майбутньому, стануть головним фактором впливу на відродження національної культури, свідоме формування гуманістичних світоглядних позицій.

Посилена активізація міжкультурних та міжнаціональних взаємодій спричинила інтеграцію української музичної освіти в європейський простір, що характеризується обміном педагогічного досвіду, культурних та духовних надбань, науково-методичними ідеями тощо.

Оскільки Україна є частиною європейського освітнього процесу, цілком закономірно, що почали змінюватися акценти і погляди на фахівця музичної галузі, зокрема виконавця- 
духовика, котрий виконує багатоаспектну діяльність - виконавець-інструменталіст, диригент, педагог, організатор. Тому актуальним і перспективним є дослідження специфіки формування фахової компетентності виконавця-духовика під час навчання у закладі вищої освіти України з опорою на європейські традиції та досвід, під впливом інтеграційних процесів та в умовах упровадження компетентнісного підходу.

Метою статті є розкриття особливостей формування та розвитку фахової компетентності виконавця-духовика у контексті інтеграційних процесів у закладах вищої освіти України.

Аналіз досліджень. Наукові дослідження музично-педагогічних концепцій вищої освіти інших європейських країн у порівняльно-історичному аспекті здійснено у працях Абашкіної Н., Лавриченко Н., Десятова Т., Матвієнко О., Наврочинського Б., Пахочинського Р., Ничкало Н., Пуховської Л., Сбруєвої А.

Вивчення і подальше обгрунтування поняття «фахова компетентність» знаходимо у напрацюваннях багатьох дослідників: Н. Бібік, І. Зимньої, І. Зязюна, А. Хуторського, В. Краєвського, О. Пометун, А. Маркової, М. Головань, Л. Карпової, О. Овчарук, О. Локшиної, В. Лозової, О. Онопрієнко, О. Савченко.

Тлумачення фахової компетентності майбутніх спеціалістів музичної сфери стало предметом зацікавлення й наукового висвітлення у роботах багатьох науковців: теоретикометодологічна й експериментальна сторони цього феномену - Л. Масол, Н. Кузьмина, О. Олексюк, I. Драч, А. Козир, В. Лозова, М. Михаськова, Р. Савченко, В. Каплінський, Т. Пляченко, А. Растригіна, О. Щолокова, Л. Карпова; основні концептуальні засади фахової підготовки майбутнього вчителя музики у вищих навчальних закладах розроблялися Е. Абдулліним, А. Болгарським, Г. Падалкою, О. Ростовським, О. Рудницькою, Л. Арчажниковою, О. Олексюк, О. Щолоковою; вивчення конкретних компетентностей майбутнього фахівця музично-мистецької галузі: І. Полубоярина, М. Михаськова, Н. Цюлюпа, Н. Мурована, С. Проворова та інші.

Опираючись на досвід вивчення особливостей фахової компетентності і беручи до уваги багатогранність і поліфункціональність означеної номінації, вважаємо, що необхідно науково висвітлити i з'ясувати специфіку фахової компетентності виконавця-духовика, оскільки існує незаповнена лакуна в цьому питанні.

Виклад основного матеріалу. Україна як європейська держава керується не лише власними науковими здобутками й досвідом, а й активно співпрацює з багатьма іншими державами, переймаючи їхні кращі методики навчання студентів. Тому європейська інтеграція для України - це, насамперед, приєднання до інших європейських народів, долучення до європейських культурних та історичних традицій.

Відображення співпраці держав у галузі освіти зафіксовано у багатьох міжнародних документах: деклараціях, конвенціях, рішеннях, які підтримані та зініційовані міжнародними організаціями (ООН, ЮНЕСКО, Міжнародною організацією праці тощо).

Тому основна стратегія участі вищої освіти України в інтеграційних процесах і активна співпраця 3 європейськими університетами спрямовується на іiі розвиток i набуття нового якісного досвіду, водночас зберігаючи кращі традиції і технології української освітньої системи.

Надзвичайно важливим є прийняття Закону України «Про вищу освіту» (2014р.), у якому зазначено, що термін вища освіта - це «... сукупність систематизованих знань, умінь $\mathrm{i}$ практичних навичок, способів мислення, професійних, світоглядних і громадянських якостей, морально-етичних цінностей, інших компетентностей, здобутих у вищому навчальному закладі (науковій установі) у відповідній галузі знань за певною кваліфікацією на рівнях вищої освіти, що за складністю $є$ вищими, ніж рівень повної загальної середньої освіти», тоді як «...якість вищої освіти - рівень здобутих особою знань, умінь, навичок, інших компетентностей, що відображає ï компетентність відповідно до стандартів вищої освіти...» [12].

Отож слід відзначити, що основними позиціями вищої освіти являються компетентності, які розглядаються у законодавчому документі як «...динамічна комбінація знань, умінь $\mathrm{i}$ практичних навичок, способів мислення, професійних, світоглядних і громадянських якостей, морально-етичних цінностей, яка визначає здатність особи успішно здійснювати професійну та подальшу навчальну діяльність і $є$ результатом навчання на певному рівні вищої освіти ...» [12].

Вважаємо доречним нагадати, що головною ідеєю загальноєвропейської інтеграції у сфері вищої освіти (зокрема, й музично-мистецької) виступає іiі стандартизація, що базується на компетентнісному підході. Цілком закономірно, що процес інтегрованого освітянського простору спричинив появу таких явищ, як неперервна освіта, навчання впродовж усього життя та освіта для дорослих. Ніколаї Г. неодноразово наголошує у своїх наукових розвідках, що у європейських 
країнах мистецькі дисципліни дедалі більше стають вагомим важелем впливу і залучення молодого покоління до загальноєвропейської культурної спадщини, фактором усвідомлення європейської приналежності з опорою на національний грунт. Тому наслідками такої діяльності стало посилення зв'язків між дисциплінами художньо-естетичного циклу у закладах вищої освіти та подальше об’єднання їх в окрему галузь - мистецьку освіту. Крім того, динамічна інтеграція музичних культур сприяла утвердженню інтеркультурної музичної педагогіки [7].

Отож, як бачимо, фахова підготовка спеціаліста мистецької галузі як і в Україні, так і в європейських країнах повинна орієнтуватися на впровадження компетентнісного підходу.

У сучасній педагогічній науці компетентнісний підхід трактується як єдина система, яка має визначену мету, зміст, і забезпечує процес підготовки майбутнього вчителя шляхом набуття спеціальних, загальних та ключових (фахових) компетенцій, що сприяють високому рівню професійно-педагогічної діяльності [4, с. 167].

Загалом основні категорії компетентнісного підходу розроблені в наукових працях Н. Бібік, . Зимньої, І. Зязюна, А. Хуторського, В. Краєвського, О. Пометун, Л. Карпової, В. Лозової, О. Онопрієнко, О. Савченко та інших науковців, котрі розмежували поняття «компетентність» та «компетенція», сформулювали концептуальні засади розвитку компетентності тощо. Опираючись на ці наукові дослідження, можемо окреслити теоретичні тлумачення термінів, а саме: компетенція являється об'єктивною категорією, сукупністю знань, умінь, навичок, ставлень. У той час як компетентність - певна інтегрована характеристика якості особистості, що сформувалася завдяки знанням, умінням i навичкам, відповідним ставленням, реакціям та спроможністю до самостійного виконання конкретних завдань.

Отож можемо стверджувати, що компетентнісний підхід визначає пріоритетним не інформованість студента, володіння знаннями, а вміння послуговуватися цими знаннями, практично застосовувати їх у фаховій діяльності, швидко приймати рішення, виявляти ініціативність та креативність у розв'язанні проблем тощо.

У той же час словник професійної освіти визначає поняття «компетентність» наступним чином: це сукупність знань та вмінь, які необхідні для ефективної професійної діяльності (аналіз, передбачення наслідків у професійній діяльності, вміння доречно і результативно послуговуватися різною інформацією) [2].

Деякі науковці ототожнюють поняття «компетентність» і «компетенція» (А. Павлова, Е. Зеєр). Однак ми схиляємося до думки більшості дослідників і вважаємо, що слід розмежовувати ці наукові поняття. Отож компетенції визначаємо як сформовані знання, уміння й навички, в той час як компетентність трактуємо в ширшому розумінні, що грунтується на системі володіння певними компетенціями, ставленні особистості до них, вмінні практично застосовувати їх у фаховій діяльності. Звідси випливає, що компетенції є основними складовими компонентами компетентності.

Набагато складнішим i поліфункціональним $є$ тлумачення поняття «фахової компетентності» майбутніх спеціалістів музичної сфери, оскільки воно включає в себе як педагогічну, так i мистецьку складові. Тому дана педагогічна категорія $є$ предметом дослідження багатьох науковців (Л. Масол, Н. Кузьмина, О. Олексюк, А. Козир, В. Лозова, М. Михаськова, Р. Савченко, Т. Пляченко, А. Растригіна, О. Щолокова, Л. Карпова та ін.), котрі вивчали як і теоретико-методологічну, так і експериментальну сторони цього феномену.

Професійна компетентність вчителя, на переконання Л. Карпової, системне, інтегративне особистісне утворення, що формується на основі теоретичних знань, умінь, індивідуальних якостей, а також певного фахового досвіду педагога, що в комплексі й визначає готовність учителя до педагогічної діяльності [4].

Л. Масол наголошує на взаємозв’ язку між особистісними, соціальними й функціональними компетентностями, які висвітлюють освітні результати як цілісні, інтегральні характеристики, в той же час вони потребують впровадження спеціальної методики, здатної діагностувати й впливати на формування компетентнісної особистості педагогічними явищами, які, в свою чергу, перебувають у тісному інтегративному переплетінні з мистецькою освітою [5, с. 17].

На думку А. Растригіної, фахова (професійна) компетентність майбутніх педагогів у сфері мистецтва складається з інтегрованих і спеціальних фахових компетенцій [13].

О. Пометун пропонує розуміти компетентність учителя як об'єктивну категорію, що вбирає в себе суспільно важливі знання, вміння, навички, ціннісні ставлення, які допомагають педагогу виконувати складні поліфункціональні, міжпредметні види діяльності [11, с. 19]. 
I. Полубоярина вважає професійну компетентність учителя музики інтегративним утворенням, поєднанням структурних компонентів (основних компетентностей), яке включає в себе музично-педагогічні знання, уміння, навички, музичні здібності тощо, що є безпосереднім виявом готовності особистості до творчої педагогічної діяльності [10].

На думку М. Михаськової, фахова компетентність майбутнього вчителя музики визначається як здатність до музично-освітньої діяльності, що грунтується на основі музичнопедагогічних знань та вмінь, сформованому ціннісному ставленні особистості до музичного мистецтва, і характеризується здатністю поєднувати музичні та педагогічні функції [6].

Результатом дослідження педагогічних основ підготовки майбутнього вчителя музики до роботи з учнівськими музично-інструментальними колективами став висновок Т. Пляченко, який дозволив означити поняття «оркестрово-методична компетентність», яке являється інтегративною рисою майбутнього педагога, адже поєднує в собі якості керівника колективу 3 особистісними професійно-педагогічними компетентностями [9].

Об'єктом дослідження С. Світайло став процес формування фахової компетентності майбутніх учителів музики диригентсько-хорового напрямку, тому фахова компетентність розглядається як інтегративна структура 3 притаманними їй здібностями, спрямованими на розвиток школярів через призму вокально-хорового співу, 3 опорою на набуті музичнопедагогічні знання та вміння, практичний досвід відповідно до суспільно-соціальних та культурно-мистецьких вимог [14, с. 26].

Інтенсивні інтеграційні процеси у галузі мистецької освіти сприяли утвердженню окремого виду міжпредметних компетентностей - мистецької компетентності майбутнього вчителя. Зокрема, у наукових дослідженнях вітчизняних фахівців (Г. Падалка, Л. Масол, О. Щолокова, О. Олексюк та ін.) знаходимо грунтовні тлумачення даного поняття, а саме: О. Щолокова [15] вважає, що фахову компетентність в галузі мистецької освіти можна розглядати синонімічно до мистецької компетентності вчителя.

Мистецька компетентність - це основа мистецької освіти, тому, за твердженням О. Олексюк, вона повинна віддзеркалювати духовне багатство особистості, іiі здатність до емоційно-ціннісного сприйняття й співпереживання, можливість створення власного творчого стилю та музично-творчої діяльності з опорою на досвід мистецьких компетенцій [8, с. 222]. Дослідниця зазначає, що мистецька компетентність вчителя музики допомагає педагогу «успішно здійснювати в змінних соціокультурних умовах професійні функції, самостійно розвивати й реалізувати набутий у процесі навчання фаховий потенціал» [8].

Отож цілком закономірно, що введення поняття «мистецька компетентність» як частини феномену професійної компетентності вчителя музики стало віддзеркаленням сучасних тенденцій, пов'язаних з інтеграційними процесами у галузі мистецької освіти. Згодом з'явилася окрема номінація - «поліхудожня компетентність» майбутнього вчителя музики, запропонована О. Боблієнко [1, с. 8].

У нашому дослідженні розглядається формування фахової компетентності не просто майбутнього вчителя музики, а ще й музиканта, який водночас є і виконавцем-духовиком, i педагогом. Оскільки сфера виконавської діяльності є поліфункціональною, тому підготовка спеціалістів у закладах вищої освіти спрямована на формування компетентностей, які необхідні майбутнім духовикам.

Отож, на наше переконання, фахова компетентність виконавців-духовиків - це інтегративне явище, основою якого є набуті у процесі навчання знання, уміння й навички, особистісні якості педагога й виконавця, сформована професійна виконавська майстерність, творча та інтерпретаційна активність, загальнокультурна ерудованість, володіння новітніми методиками викладання, використання педагогічного й виконавського вітчизняного досвіду, вивчення європейських сучасних технологій, гармонічне поєднання української культурної спадщини 3 європейською, що й передбачає здатність і готовність виконавця-духовика до педагогічної, інструментально-виконавської та творчої діяльності.

Професійна компетентність виконавців-духовиків характеризується наявністю взаємопов’ язаних ключових музичних компетенцій, які, в свою чергу, є системним утворенням, накопиченням музично-педагогічних знань, сформованих музично-виконавських умінь та особистісного музично-творчого досвіду. Ми схиляємося до думки, що оволодіння необхідними музичними компетенціями стане ядром для вдосконалення i подальшої самореалізації виконавця-духовика, розвитку й інших предметних компетенцій, важливих для музично-педагогічної діяльності загалом. 
Тому вважаємо актуальним виокремлення наступних музичних компетенцій виконавияядуховика:

- теоретико-методична (наявність фахових музичних теоретичних знань, розуміння методики викладання фахових дисциплін);

- інструментально-виконавська (практичне застосування навичок гри на духових інструментах, формування музично-виконавської майстерності, ціннісного мистецького досвіду);

- креативно-відтворювальна компетенція (здатність до інтерпретаційного вираження музичних творів, вміння імпровізувати, володіння творчим підходом у навчанні гри на духових інструментах, композиторські здібності, можливість до творчого самовираження тощо);

- соціально-активна компетенція (володіння навичками професійного спілкування, роботи в колективі, розуміння соціальної відповідальності за виконану професійну діяльність тощо);

- особистісно-психологічна компетенція (толерантність, вихованість, стриманість, організаторські здібності, вміння продуктивно планувати робочий час, тактовність, емоційна стабільність, вміння співпереживати, можливість професійної ідентифікації та самореалізації тощо).

Діяльність виконавця-духовика характеризується складністю ще й тому, що музичновиконавський процес потребує досконалого поєднання таких складових, як виконавський апарат, володіння аплікатурою, артикуляцією, виконавськими засобами (звукоутворення, інтонація, динаміка, вібрато, штрихи, фразування, ритм, метр, темп, агогіка, розвиток музичного слуху, постановки, техніки дихання тощо).

Висновки. Отже, у нашому дослідженні ми дійшли висновків, що реалізація компетентнісного підходу в закладах вищої освіти України спрямована на підготовку конкурентоспроможних фахівців, котрі володіють інтегративною системою знань, практичних умінь у конкретній галузі. Формування фахової компетенції майбутніх спеціалістів відбувається під впливом європейського передового досвіду зі збереженням українських традицій.

Таким чином, проаналізувавши багатоаспектність компетентнісного підходу в музичнопедагогічній галузі та спроектувавши актуальність досліджуваної теми на духове виконавство, ми дійшли висновку, що розвиток фахової компетентності виконавців-духовиків являється інтегративним поліфункціональним утворенням і заслуговує на особливу увагу та подальше детальне вивчення у контексті процесів європейської інтеграції.

\section{ЛІТЕРАТУРА}

1. Боблієнко, О. П. (2013). Формування поліхудожньої компетентності майбутнього вчителя музики у процесі фахової підготовки. (Автореферат дисертації кандидата педагогічних наук). Вінниця.

2. Бусел, Т. В. (2004). Великий тлумачний словник сучасної української мови. Київ; Ірпінь: Перун.

3. Гаврілова, Л. Г. (2015). Система формування професійної компетентності майбутніх учителів музики засобами мультимедійних технологій. (Дисертація доктора педагогічних наук). Київ.

4. Мархадаев, Л. В. (2002). Словарь по соииальной педагогике: Учебное пособие. Москва: Издательский центр "Академия".

5. Масол, Л. М., Миропольська, Н. Є, Рагозіна, В. В. (2010). Формування базових компетентностей учнів загальноосвітньої школи у системі інтегративної мистецької освіти: посібник для вчителя. Київ: Педагогічна думка.

6. Михаськова, М. А. (2007). Формування фахової компетентності майбутнього вчителя музики. (Дисертація кандидата педагогічних наук). Київ.

7. Ніколаї, Г. Ю. (2013). Методологічні пошуки у сфері мистецької освіти. Актуальні питання мистецьької освіти та виховання. Вип 1, 3-17.

8. Олексюк, О.М.(2013). Музична педагогіка: Навчальний посібник. Київ: Київський університет ім. Б. Грінченка.

9. Пляченко, Т. М. Компетентнісна модель у структурі фахової підготовки майбутнього вчителя музики. Retrieved from http://elibrary.kubg.edu.ua/570/1/T_Plyachenko_Kompetentnisna\%20model.pdf

10. Полубоярина, I. I. (2008) Формування професійної компетентності майбутніх учителів музики в педагогічному коледжі. (Автореферат дисертації кандидата педагогічних наук). Житомир.

11. Пометун, О. I. (2005) Формування громадянської компетентності: погляд з позиції сучасної педагогічної науки. Вісник програм шкільних обмінів. 23, 18-20.

12. Про вищу освіту: Закон України 2014, № 1556-VII від 01. 07. 2014. Режим доступу : http://vnz.org.ua/zakonodavstvo/111-zakon-ukrayiny-pro-vyschu-osvitu.

13. Растригіна, А. М. (2012). Компетентнісний підхід до підготовки майбутнього магістра музичного мистецтва. Сучасні стратегії університетської освіти: якісний вимір, 501-509.

14. Світайло, С. В. (2012). Формування фахової компетентності майбутніх учителів музики у процесі диригентсько-хорової підготовки. (Дисертація кандидата педагогічних наук). Київ.

15. Щолокова, О. П. (2006). Професійна компетентність як стратегічний напрямок модернізації мистецької освіти України. Вісник Глухівського державного університету. Вип. 8, 19-23. 